\title{
The energetic impact of overwinter prey assemblages on age-0 largemouth bass, Micropterus salmoides
}

\author{
Kenneth G. Ostrand ${ }^{\mathrm{a}}$, Steven J. Cooke ${ }^{\mathrm{b}, \mathrm{d}}$, James E. Garvey ${ }^{\mathrm{c}}$, \& David H. Wahl ${ }^{\mathrm{a}, \mathrm{b}}$ \\ ${ }^{a}$ Center for Aquatic Ecology, Illinois Natural History Survey, Sam Parr Biological Station, 6401 Meacham \\ Road, Kinmundy, IL 62854,U.S.A. (e-mail: ostrand@uiuc.edu) \\ ${ }^{\mathrm{b}}$ Department of Natural Resources and Environmental Sciences, University of Illinois and Center for Aquatic \\ Ecology, Illinois Natural History Survey, 607 E. Peabody Dr., Champaign, IL 61820, U.S.A \\ ${ }^{\mathrm{c}}$ Fisheries and Illinois Aquaculture Center, Department of Zoology, Southern Illinois University, Carbondale, \\ IL 62901, U.S.A \\ ${ }^{\mathrm{d}}$ Current address: Center for Applied Conservation Research, University of British Columbia, 2424 Main \\ Mall, Vancouver, British Columbia, V6R 2J3 Canada
}

Received 19 June $2003 \quad$ Accepted 12 July 2004

Key words: Micropterus salmoides, swimming performance, growth, forage, temperature

\section{Synopsis}

We compared survival, growth, and swimming performance of two size classes of age-0 largemouth bass, Micropterus salmoides, in the spring after being fed diets of bluegill, Lepomis macrochirus, fathead minnows, Pimephales promelas, or invertebrate prey during the winter. Regardless of prey assemblage, survival was uniformly high and independent of size. Length, wet- and dry-mass, and condition was also similar among treatments for both size classes. However, variation in individual performance differed, with the lowest variability in growth occurring among small age- 0 largemouth bass in the invertebrate only treatment. Absolute and length corrected swimming speeds of largemouth bass were highest for invertebrate prey assemblages, intermediate for fathead minnow prey, and lowest for bluegill prey. The patterns in growth and spring swimming performance likely reflect the varied nutritive quality of different prey, the ability of largemouth bass to capture different prey, and competition with the piscine prey.

\section{Introduction}

At southern and mid-temperate latitudes winter temperatures and prey assemblages vary among lakes and years. Age-0 largemouth bass forage during the winter at these latitudes when temperatures are high enough to advance growth coupled with abundant prey (Garvey et al. 1998, Fullerton et al. 2000, Micucci et al. 2003). Because activity levels and metabolic rates are low in the winter, small amounts of exogenous energy have the potential to provide substantial benefit to fish (Garvey et al. 1998, Wright et al. 1999, Fullerton et al. 2000). However, these benefits may not simply be influenced by the quantity of prey but also the quality of prey because different species of prey exhibit dissimilar caloric values, levels of winter activity, and habitat use (Davis \& Boyd 1978, Ludsin \& DeVries 1997). In addition, these effects may differ with the size of age-0 largemouth bass (Ludsin \& DeVries 1997). For example, larger fish should ingest more energy per gram than smaller counter parts (Ludsin \& DeVries 1997). Differences in prey consumption, including predator-prey encounter rates and prey quality, should affect survival, growth, and energetic performance patterns among age-0 largemouth bass through winter until early spring and these relationships may vary with size. 
Our objective was to examine the effects of common overwinter prey assemblages (1) natural invertebrate forage, (2) cyprinids and natural invertebrate forage, and (3) centrarchids and natural invertebrate forage on two size classes of age0 largemouth bass after the first winter. We hypothesized that if prey type were an important determinant of overwinter feeding that survival, growth, and swimming performance would vary among treatments. Swimming performance requires the integration of numerous physiological processes that can provide information on the general health, energetics, nutritional status, and stress levels of fish (Schreck 1990). Swimming performance post-winter would be a sensitive and ecologically relevant indicator of the effects of overwinter prey assemblage, and would permit inferences about variation in endogenous energy levels. Fish that emerge from the winter in better condition and with enhanced swimming performance would likely be more efficient at foraging and evading predators (Plaut 2001).

\section{Materials and methods}

We conducted experiments in nine 0.04 ha ponds located in central Illinois at the Sam Parr Biological Station (Latitude: $38^{\circ} 42^{\prime} 50.0 \mathrm{~N}$, Longitude: $\left.88^{\circ} 44^{\prime} 55.0 \mathrm{~W}\right)$. The ponds have clay substrates and support sparse aquatic vegetation and naturally colonized invertebrates. To obtain estimates of abundance and diversity of invertebrates we sampled the littoral zones of the ponds with a $20 \mathrm{~cm}$ diameter stovepipe sampler $(\mathrm{N}=4$ per pond) prior to age- 0 largemouth bass introductions in November and at the completion of the experiment in April. We fixed the samples in Rose Bengal solution in situ and hand picked them in the laboratory and identified all macroinvertebrates to the lowest possible taxa under a stereomicroscope (Merritt \& Cummins 1996). Densities of macroinvertebrates were arcsine-square-root transformed prior to analysis. Differences among ponds with differing overwinter prey types at the onset and completion of the experiment were compared using multivariate analysis of variance (MANOVA, $p<0.05$, SAS 1999).

We obtained bluegill, Lepomis macrochirus, from Little Grassy State Fish Hatchery, Carbon- dale, Illinois, and fathead minnows, Pimephales promelas, from Pana Bait Company, Pana, Illinois in September. We collected 675 age- 0 largemouth bass from experimental ponds at the Sam Parr Biological Station, Kinmundy, Illinois in October and marked two size classes (large $=100-130 \mathrm{~mm}$ total length, TL and small $=80-90 \mathrm{~mm}$ TL) with pelvic fin clips.

Prior to age- 0 largemouth bass introductions we stocked six of the ponds with prey on 1 November 2000 at a density of 1.5 times the overwinter maintenance ration of the bass. Three ponds had bluegill $(\mathrm{N}=10800$ per pond, mean $=23.02 \pm 0.25 \mathrm{~mm}$, $\mathrm{TL}$, mean $=0.17 \pm 0.01 \mathrm{~g}$ ) and three were stocked with fathead minnows $(\mathrm{N}=2482$ per pond, mean $=47.63 \pm 0.70 \mathrm{~mm}, \quad \mathrm{TL}, \quad$ mean $=0.89$ $\pm 0.39 \mathrm{~g})$. We determined maintenance rations from the Hewett \& Johnson (1992) bioenergetics model, in which winter durations and temperatures in the model were derived from averages for the latitude of the winter pond experiment (Garvey et al. 1998). We assumed energy densities of both prey fishes and age-0 largemouth bass to be 1000 calories $\mathrm{g}^{-1}$. We then determined the total mass of fish prey necessary to maintain wet mass of average-sized small and large age- 0 largemouth bass under normal winter conditions. The total number of prey stocked into each pond was determined by dividing the predicted total mass consumed by the average individual mass of each prey species. Sizes of both bluegill and fathead minnows were vulnerable to largemouth bass given their gape size at the beginning of the experiment. Ponds containing bluegill and fathead minnows also had natural invertebrate forage. The three remaining ponds contained only natural invertebrate populations as forage for largemouth bass.

In mid-November we stocked each pond with 50 small (mean $=83.6 \pm 0.19 \mathrm{~mm}$, total length, TL, mean $=5.64 \pm 0.29 \mathrm{~g})$ and 25 large $($ mean $=$ $108.38 \pm 0.67 \mathrm{~mm}$, total length, TL, mean = $14.46 \pm 1.35 \mathrm{~g}$ ) age-0 largemouth bass. Water temperature at time of stocking was $14^{\circ} \mathrm{C}$ and decreased steadily until mid-December when all ponds had ice cover and reached water temperatures below $4^{\circ} \mathrm{C}$. Ice cover deteriorated in mid-February and water temperatures increased gradually to $10^{\circ} \mathrm{C}$ in mid-March. Fish foraged under natural conditions for $145 \mathrm{~d}$ until early April. We drained ponds over a 3 day period when water temperatures reached 
$20^{\circ} \mathrm{C}$ and identified all collected largemouth bass by pelvic fin clips and counted all remaining bluegill $\left(\right.$ mean $\left.=4 \mathrm{~m}^{-2}\right)$ and fathead minnows (mean = $2 \mathrm{~m}^{-2}$ ). We then weighed and measured largemouth bass and calculated a Fulton-type condition factor (K; Anderson \& Gutreuter 1983). A size-stratified sub-sample of largemouth bass was dried at $60^{\circ} \mathrm{C}$ to a constant mass and re-weighed $(\mathrm{N}=25$ per pond for small and $\mathrm{N}=20$ per pond for large size class).

We used a completely randomized experimental design and nested mixed model analysis of variance (ANOVA) to test for differences $(p<0.05)$ in TL, K, and wet- and dry-weight for each size class among treatments. To meet assumptions of the ANOVA we log $10^{-}$transformed independent variables. We used Levene's Test for heterogenous variances to examine the distribution of untransformed TL and wet-weight errors for each size class among treatments and used ANOVA to test for significant differences $(p<0.05)$ among the treatment errors. Fisher's LSD mean separation tests for pairwise comparisons followed significant ANOVAs (SAS 1999). We examined overwinter survival among size classes and forage assemblages for differences $(p<0.05)$ using Chi-square tests (Sokal \& Rohlf 1969).

Because smaller individuals are considered to be the most vulnerable to predation and to stress from starvation we performed swimming performance challenges on a sub-sample of these individuals. Estimates of swimming performance should provide a measure of predator avoidance and prey capture ability. We transferred 8 to 15 small age- 0 largemouth bass $($ mean $=$ $85.7 \pm 0.6 \mathrm{~mm}, \mathrm{TL}$ ) from each pond to temperature-controlled tanks $\left(20 \pm 1^{\circ} \mathrm{C}\right)$ with natural photoperiod. To ensure a post-absorptive state we held individual fish for $48 \mathrm{~h}$ prior to experimentation (Beamish 1978) and then placed them into the swimming chamber. We conducted swimming challenges in a 56-L modified Blazka type swim chamber as described by Cooke et al. (2001). The swim chamber was continuously supplied with aerated water at $20 \pm 1{ }^{\circ} \mathrm{C}$ and operated on a flowthrough basis during the swimming challenges. We acclimated fish at a water flow rate of $0.03 \mathrm{~m} \mathrm{sec}^{-1}$ ( $\sim 0.5$ body lengths $\mathrm{sec}^{-1}$ ) for $20 \mathrm{~min}$ (Peake et al. 1997). A light gradient was used to encourage fish to swim. Following acclimation, we exposed fish to a series of stepwise velocity increments to determine their maximum aerobic swimming capacity (critical swimming velocity, U-crit, Beamish 1978). The velocity was increased by $0.07 \mathrm{~m} \mathrm{sec}^{-1}$ increments every $10 \mathrm{~min}$, until the test fish were fatigued. Fatigue was defined as the point at which the fish became impinged on the rear-blocking screen twice and refused to swim, despite temporary changes in flow or tapping on the side of the chamber (Peake et al. 1997). We removed fatigued fish from the chamber and measured (TL), and weighed (g) them. Using the formula outlined in Beamish (1978) critical swimming speed was calculated and expressed both in absolute $\left(\mathrm{cm} \mathrm{sec}^{-1}\right)$ terms and in body lengths per second to account for variation in fish length (Hammer 1995). We used nested mixed model ANOVA to test for significant differences $(p<0.05)$ in untransformed absolute critical swimming speed (U-Crit) and length corrected swimming speeds (in body lengths (BL)/per second) among treatments. Fisher's LSD mean separation tests for pairwise comparisons followed significant ANOVAs (SAS 1999).

\section{Results}

Macroinvertebrate relative abundance and assemblage structure was similar (MANOVA: Wilks Lambda $=0.19, p=0.55$ ) among the three treatments at the onset of the experiment. Nematoda $(38 \%)$ comprised the greatest relative abundance followed by chironomidae (33\%), ceratopogonidae $(20 \%)$, gastropoda $(5 \%)$, ostracoda $(2.5 \%)$ and pelecypoda $(1.5 \%$, Figure 1). Nematoda and ostracoda relative abundance decreased and ceratopogonidae increased among all ponds during the winter; however there were no significant differences (MANOVA: Wilks Lambda $=0.31$, $p=0.45$ ) among the three treatments at the end of the experiment (Figure 1).

Overall mortality of age-0 largemouth bass was low (mean 11\%). The number of individuals that were lost to overwinter mortality for the small size class (mean $15 \%)$ of bass was higher $\left(\chi_{2}^{2}=2.15\right.$, $p=0.04$ ) than the large size class (mean $4 \%$ ). The average mortality of the small and large size class of bass within bluegill ponds was 21 and $9 \%$ respectively, compared to 12 and $1 \%$ respectively for fathead minnow ponds, and 12 and $3 \%$ respectively in macroinvertebrate ponds. Both size classes of 


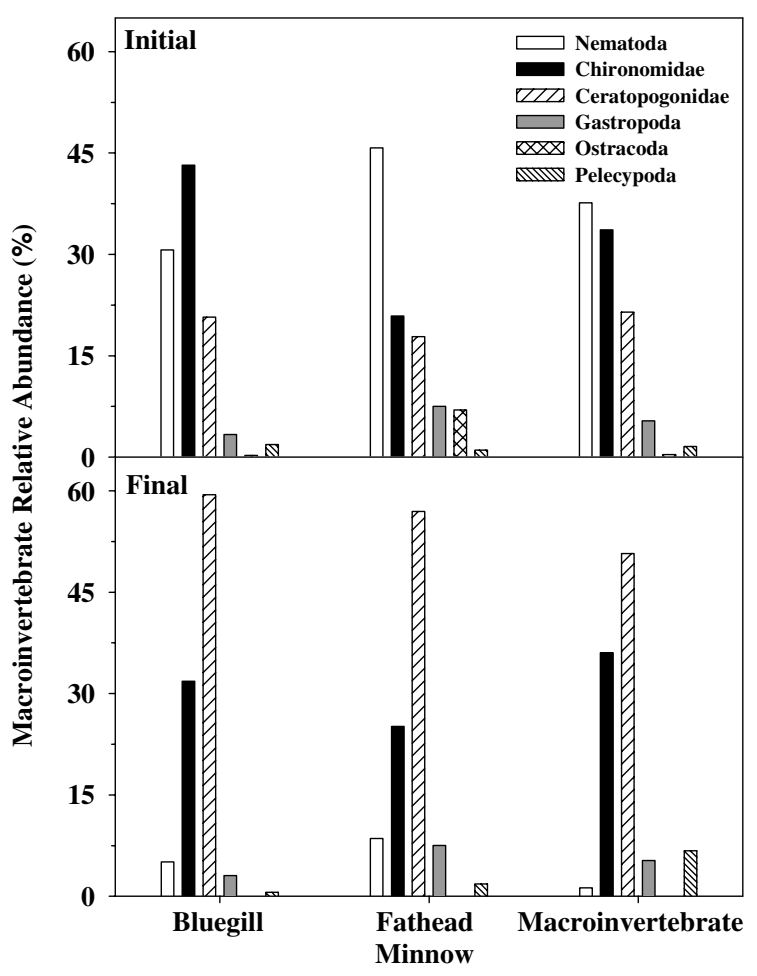

Figure 1. Winter macroinvertebrate relative abundance (\%) within 0.04 ha experimental ponds located in central Illinois. Three of the nine ponds had bluegill and macroinvertebrates, three ponds had fathead minnows and macroinvertebrates, and the remaining three ponds had only macroinvertebrates as available forage for age-0 largemouth bass.

largemouth bass among all treatment forage types grew $\left(\right.$ mean $_{\text {small size class }}=4.43 \mathrm{~mm}$, TL, mean $=$ $1.83 \mathrm{~g}$; mean $_{\text {large size class }}=7.11 \mathrm{~mm}, \mathrm{TL}$, mean $=$ $4.7 \mathrm{~g}$ ) over the winter (Figure 2). Changes in length (ANOVA: $p=0.79$ ), wet-weight (ANOVA: $p=0.75$ ), dry-weight (ANOVA: $p=0.69$ ), and K (ANOVA: $p=0.42$ ) were not related to forage type across both large and small size classes. Weight of individuals within the small size class of age-0 largemouth bass that fed on macroinvertebrates were significantly less heterogeneous (Levene's: $p<0.01$ ) than those that fed on bluegill and fathead minnows, which did not differ from one another (Figure 3). The distribution of individual TL of both the large and small size classes and the weights of the large size class among feeding treatments were homogeneous ( $p$ 's $>0.05)$.

Absolute critical swimming speed varied among age-0 largemouth bass that overwintered in ponds with different forage (ANOVA: $p<0.01$; Figure 4). Absolute critical swimming speed was higher for those foraging on invertebrates than those foraging on bluegill. Absolute critical swimming speeds were intermediate and not significantly different from the other two prey types for largemouth bass feeding upon fathead minnows. Length corrected swimming speeds in body lengths (BL)/per second also differed (ANOVA: $p<0.01$ ) among largemouth bass foraging on different prey (Figure 4). Length corrected swimming speeds for largemouth bass foraging on invertebrates or fathead minnows were similar but were lower for those feeding on bluegill (ANOVA: $p<0.01)$.

\section{Discussion}

The general paradigm is that smaller individuals with lower total energy content typically suffer higher winter mortality than larger counterparts (Garvey et al. 1998; Fullerton et al. 2000). Contrary to these studies, we found neither slow firstsummer growth nor overwinter prey assemblage resulted in poor recruitment. High survival of largemouth bass in our experiments was most likely due to the lack of predation and intraspecific competition for prey (Garvey et al. 1998). We suspect that overwinter survival will vary greatly depending upon system-specific characteristics such as abiotic conditions, predation pressure, and intra and interspecific competition.

The patterns of individual age- 0 largemouth bass growth we observed suggest an energetic cost associated with overwinter piscivory, especially for smaller individuals. Although on average largemouth bass performed similarly during the winter, a few individuals in the fish prey treatments were able to consume more fish than other individuals. Differences were probably due to interspecific variation in winter habitat use, encounter rates, or subtle differences in gape size (sensu Micucci et al. 2003). Although the ponds are generally homogeneous, piscine prey may partition habitats spatially (Miranda \& Hubbard 1994) and exhibit temporal variation in habitat use or activity patterns. Although little is known about winter activity of bluegill some typically diurnal fish including minnows become nocturnal at low temperatures 


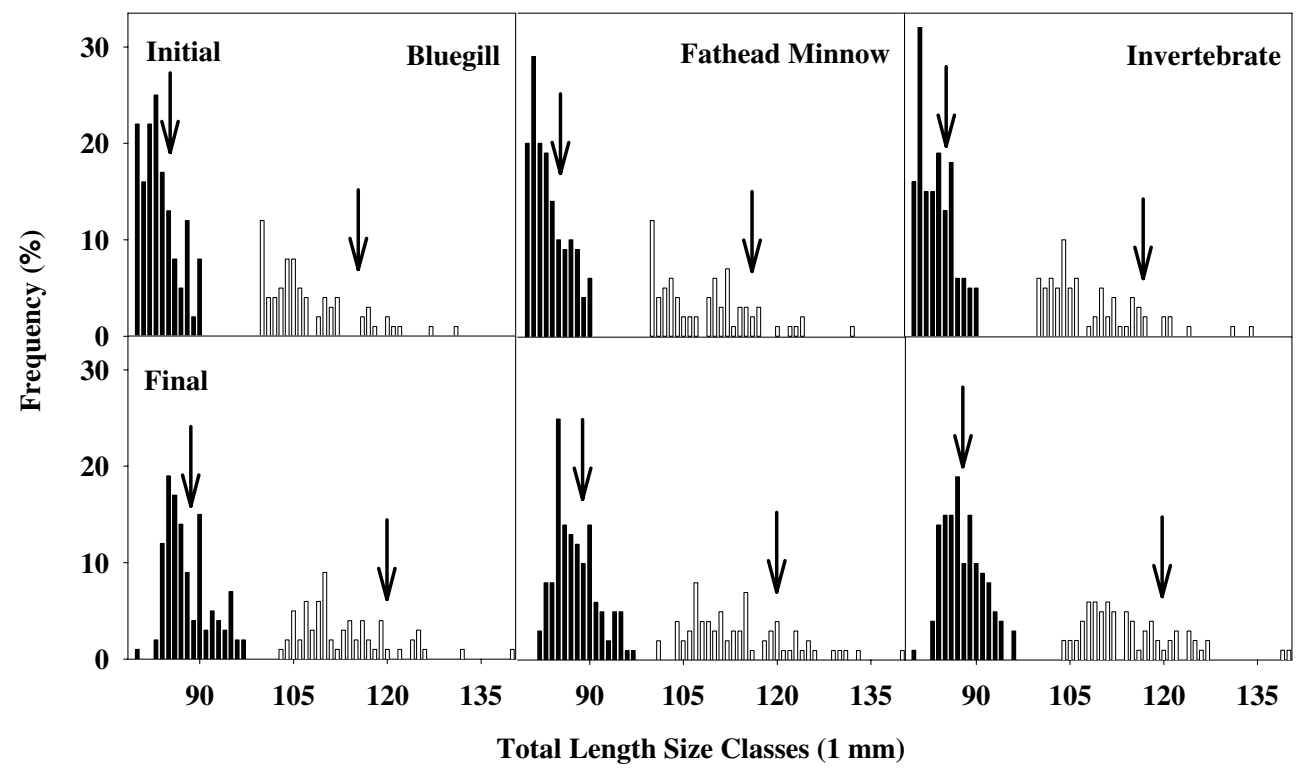

Figure 2. Initial and final length distribution histograms of age-0 largemouth bass overwintering on three forage types (i.e., bluegill, fathead minnows, invertebrates) in experimental ponds in central Illinois. Arrows denote mean size for small (filled bars) and large (open bars) size classes among treatments.

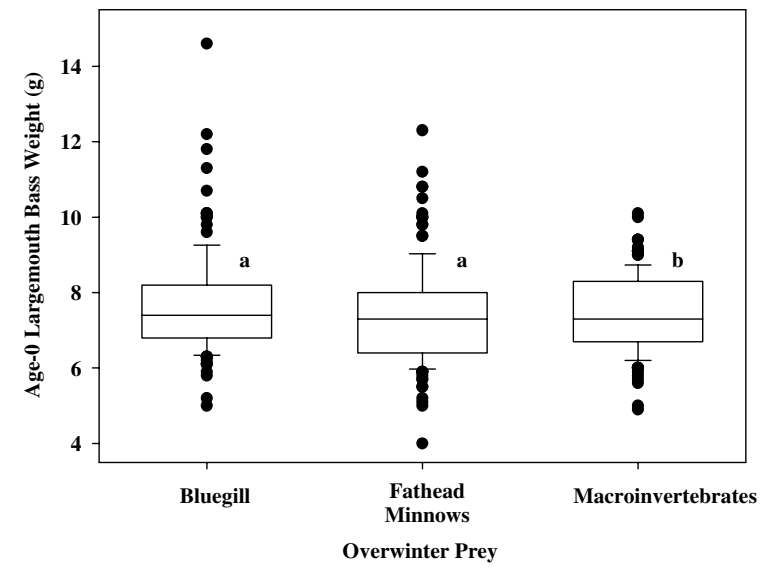

Figure 3. Box plots of individual variability in weight among age-0 largemouth bass (small size class) overwintering on three prey assemblages. For each treatment (i.e., macroinvertebrates, bluegill, and fathead minnows) the rectangle box encompasses the median (represented by the horizontal line through the box) and the 25th and 75th percentile. Above and below the box are lines extending to values of 1.5 times the interquartile range; filled circles represent values outside these ranges. Boxplots not sharing the same letter differ in heterogeneity (Levene's Test, $p<0.05)$.

(Greenwood \& Metcalfe 1998). In contrast, largemouth bass generally exhibit crepuscular activity patterns in all seasons (Demers et al.
1996). At cool temperatures, largemouth bass foraging efficiency and encounter rates decrease as they exhibit reduced activity and swimming performance. Both bluegill (Bulow et al. 1981) and fathead minnows (Klinger et al. 1982) are generally believed to exhibit similar low levels of winter activity. Thus, the largemouth bass in ponds with bluegill and fathead minnows may have expended substantial energy unsuccessfully attempting to capture piscine prey, leading to their more variable weight in the spring. In contrast largemouth bass in ponds with only invertebrates could only focus their foraging activity on invertebrates. Therefore, largemouth bass consuming just invertebrates experienced less variability in the energetic cost of foraging and individuals were in similar condition. These differences may affect foraging success, predation evasion, and survival later in life as suggested by the differences we observed in critical swimming speeds.

Because the size and weight of fish did not account for differences in swimming performance, we assume that the variation in performance that we observed in spring is related to varied energy content and nutritional status of prey. Largemouth bass that consume relatively large piscine forage in the winter may have slow digestion and 


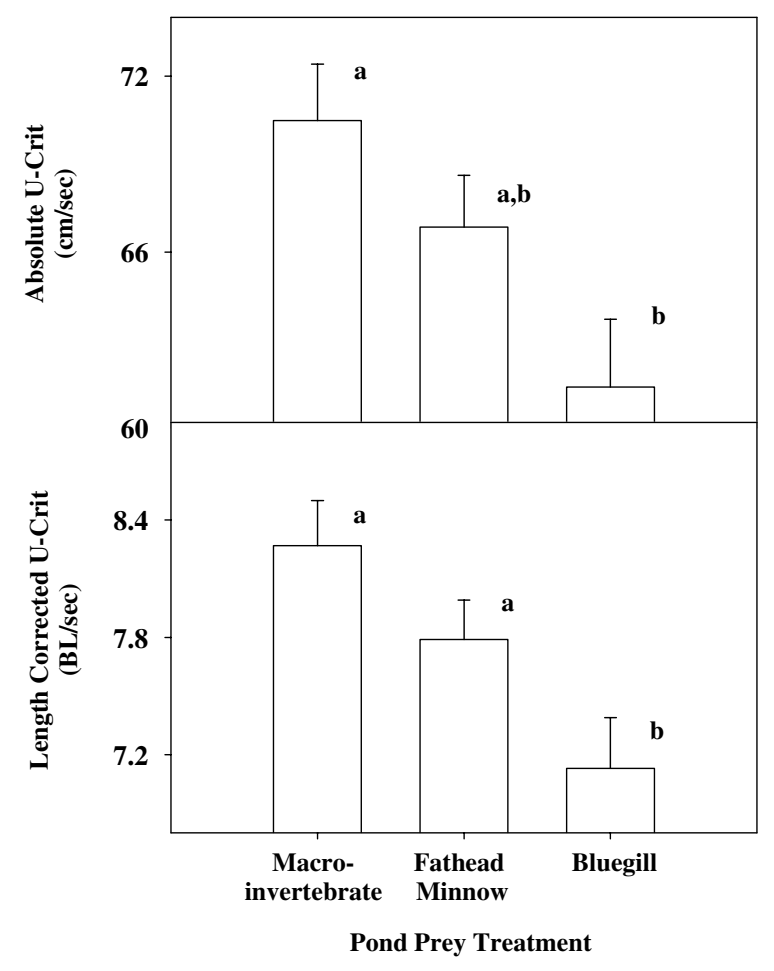

Figure 4. Swimming performance of age-0 largemouth bass (small size class) following winter in ponds with different prey assemblages. Swimming performance is reported in both absolute $\left(\mathrm{cm} \mathrm{sec}^{-1}\right.$, Upper Panel) and relative (body lengths persecond, Lower Panel) U-Crit. Different letters represents treatments that are significantly different. Values represent means (bars) \pm 1 standard error.

assimilation rates (Fänge \& Grove 1979). Alternatively, largemouth bass can consume invertebrates in small quantities as they are encountered and digest them before ingesting more food. In winter, fish may favor consuming more, but smaller rations, rather than larger rations less frequently. Indeed, in a related experiment in which age-0 largemouth bass resided in either pools with bluegills only or with bluegills plus macroinvertebrates during winter, individuals consumed bluegills when they were solely available but selected macroinvertebrates over bluegill when both prey were present (Micucci et al. 2003). Dietary protein content (Beamish et al. 1989) and fatty acid composition (McKenzie et al. 1998) have been reported to affect swimming performance. Differences in diet and nutrition may explain the variation we observed in swimming performance despite the lack of differences in dry mass.
Competition for invertebrate prey could occur among the piscine prey and largemouth bass. Bluegill are known to consume moderate quantities of benthic invertebrates in the winter (Bulow et al. 1981) and have the potential to deplete local abundance of chironomids and alter benthic community structure (Gilinski 1984). Fathead minnows also consume invertebrates (Ludwig 1996), but usually focus on zooplankton (Hambright \& Hall 1992) that are only present in low quantities during winter. Bluegill are likely stronger competitors with largemouth bass than fathead minnows. Our data suggests an inverse relationship between competition for invertebrates and swimming performance. Although we did not observe differences in invertebrate biomass among the ponds at the completion of the experiment, macroinvertebrate abundance and structure may have varied during the six-month experimental period. Additional experiments will be required to examine the potential role of macroinvertebrate abundance and dynamics on age-0 largemouth bass energetics.

The enhanced swimming performance exhibited by largemouth bass feeding solely on invertebrates could result in numerous ecological and fitness benefits. Differences in swimming performance are indicative of variation in the general health and energetic status of fish (Plaut 2001). Thus, overwinter prey assemblages have the potential to affect energy stores of fish, indirectly affecting spring foraging, predator avoidance, and thus chance of survival. In lotic environments, largemouth bass with enhanced swimming abilities would be less likely to be displaced by spring freshets. Fish that emerge from winter in better condition will also be better able to participate in reproductive activities including migration, spawning and parental care. We encourage future investigations on the role of overwinter prey assemblage on other species of fish as a function of latitude, temperature, and systems; including the role of diet and nutrition on swimming performance.

\section{Acknowledgements}

We thank K. Deters, T. Jaecks, and B. Braeutigam for field assistance. We thank A. Brandenburg and the staff of Little Grassy Fish Hatchery for 
providing bluegill. This work was conducted in accordance with procedures of the University of Illinois Office of Lab Animal Research. The University of Illinois Research Board provided funding for purchase of equipment through two grants: one to D. Philipp and S. Cooke and a second to K. Ostrand. The Federal Aid in Sport Fish Restoration through project F-135-R5 administered by the Illinois Department of Natural Resources, IDNR, provided partial funding. S. Stuewe, S. Pallo, M. Conlin, and L. Dunham coordinated activities with IDNR. The Illinois Natural History Survey and Southern Illinois University provided additional funding for the project. S. Cooke was supported by a Natural Sciences and Engineering Research Council of Canada Julie Payette Postgraduate Fellowship.

\section{References}

Anderson, R.O. \& S.J. Gutreuter. 1983. Length, weight, and associated structural indices. pp. 283-300. In: L.A. Nielson \& D.L. Johnson (ed.), Fisheries Techniques, American Fisheries Society Bethesda, Maryland.

Beamish, F.W.H. 1978. Swimming capacity. pp. 101-189. In: W.S. Hoar \& D.J. Randall (eds.), Fish Physiology, Volume 7, Academic Press, New York.

Bulow, F.J., M.E. Zeman, J.R. Winningham \& W.F. Hudson. 1981. Seasonal variations in RNA-DNA ratios and in indicators of feeding, reproduction, energy storage and condition in a population bluegill, Lepomis macrochirus. J. Fish Biol. 18: $237-244$.

Cooke, S.J., T.A. Kassler \& D.P. Philipp. 2001. Physiological performance of largemouth bass related to local adaptation and interstock hybridization: Implications for conservation and management. J. Fish Biol. 58: 248-268.

Davis, J.A., \& C.E. Boyd. 1978. Concentrations of selected elements and ash in bluegill (Lepomis macrochirus) and certain other freshwater fish. T. Am. Fish. Soc. 108: 862-867.

Demers, E., R.S. McKinley, A.H. Weatherley \& D.J. McQueen. 1996. Activity patterns of largemouth and smallmouth bass determined with electromyogram biotelemetry. T. Am. Fish. Soc. 125: 434-439.

Fänge, R. \& D. Grove. 1979. Digestion. In: W.S. Hoar, D.J. Randall \& J.R. Brett (eds.), Fish Physiology, Vol. VIII, Academic Press, New York.

Fullerton, A.H., J.E. Garvey, R.A. Wright \& R.A. Stein. 2000. Overwinter growth and survival of largemouth bass: Interactions among size, food, and winter duration. T. Am. Fish. Soc. 129: 1-12.

Garvey, J.E., R.A. Wright \& R.A. Stein. 1998. Overwinter growth and survival of age-0 largemouth bass: Revisiting the role of body size. Can. J. Fish. Aquat. Sci. 55: 2414-2424.
Gilinski, E. 1984. The role of fish predation and spatial heterogeneity in determining benthic community structure. Ecology 65: 455-468.

Greenwood, M.F.D. \& N.B. Metcalfe. 1998. Minnows become nocturnal at low temperatures. J. Fish Biol. 53: 25-32.

Hambright, K.D. \& R.O. Hall. 1992. Differential zooplankton feeding behaviors, selectivities, and community impacts of two planktivorous fishes. Environ. Biol. Fish. 35: 401-411.

Hammer, C. 1995. Fatigue and exercise tests with fish. Comp. Biochem. Physiol. 112A: 1-20.

Hewett, S.W. \& B.L. Johnson. 1992. Fish Bioeneregetics. University of Wisconsin Sea Grant, Wisconsin.

Klinger, S.A., J.J. Magnuson \& G.W. Gallepp. 1982. Survival mechanisms of central mudminnow (Umbra limi), fathead minnow (Pimphales promelas) and brook stickleback (Culaea inconstans) for low oxygen concentrations. Environ. Biol. Fish. 7: 113-120.

Ludsin, S.A. \& D.R. DeVries. 1997. First year recruitment of largemouth bass: Interdependency of early life stages. Ecol. Appl. 8: 88-103.

Ludwig, G.M. 1996. Seasonal growth and survival of rosy red and normal-colored fathead minnows receiving different feed rations. Progressive Fish-Culturist 58: 160-166.

McKenzie, D.J., D.A. Higgs, B. Dosanjh, G. Deacon \& D.J. Randall. 1998. Dietary lipid composition influences swimming performance in Atlantic salmon (Salmo salar) in seawater. Fish Physiol. Biochem. 19: 111-122.

Merritt, R.W. \& K.W. Cummins. 1996. An Introduction to the Aquatic Insects of North America. Kendall-Hunt Publishing Company Dubuque, Iowa. 000 pp.

Micucci, S.M., J E. Garvey, R.A. Wright \& R.A. Stein. 2003. Individual growth and foraging responses of age-0 largemouth bass to mixed prey assemblages during winter. Environ. Biol. Fish. 67: 157-168.

Miranda, L.E. \& W.D. Hubbard. 1994. Length-dependent winter survival and lipid composition of age-0 largemouth bass in Bay Springs Reservoir, Mississippi. T. Am. Fish. Soc. 123: 80-87.

Peake, S., C. Barth \& R.S. McKinley. 1997. Effects of recovery parameters on critical swimming speed of juvenile rainbow trout (Oncorhynchus mykiss). Can. J. Zool. 75: 1724-1727.

Plaut, I. 2001. Critical swimming speed: Its ecological relevance. Comp. Biochem. Physiol. 131A: 41-50.

SAS Institute Inc. 1999. SAS Users Guide: Statistics, version 7.0. SAS Institute, Cary, North Carolina, U.S.A.

Schreck, C.B. 1990. Physiological, behavioral and performance indicators of stress. American Fisheries Society Symposium 8: 29-37.

Sokal, R.R. \& F.J. Rohlf. 1981. Biometry. W.H. Freeman and Company, New York.

Taylor, B.W., C.R. Anderson \& B.L. Peckarsky. 1999. Delayed egg hatching and semivoltinism in neartic stonefly Megarcys signata (Plecoptera: Perlodidae). Aquat. Insect. 21: $179-185$.

Wright, R.A., J.E. Garvey, A.H. Fullerton \& R.A. Stein. 1999. Using bioenergetics to explore how winter conditions affect growth and consumption of age-0 largemouth bass. T. Am. Fish. Soc. 128: 603-612. 